\title{
ANALISIS KESERAGAMAN ASPEK FERTIGASI PADA DESAIN SISTEM HIDROPONIK DENGAN PERLAKUAN KEMIRINGAN TALANG
}

\author{
Analysis of Uniformity in Fertigation Aspects at Design of Hydroponic System \\ using Pipe Slope Variation
}

\author{
Medi Sopian Asmana ${ }^{1}$, Sirajuddin Haji Abdullah ${ }^{1, *)}$, Guyup Mahardhian Dwi Putra ${ }^{1}$ \\ ${ }^{1}$ Program Studi Teknik Pertanian Fakultas Teknologi Pangan dan Agroindustri \\ Universitas Mataram \\ Email $^{*}$ : sirajuddinhajiabdullah@gmail.com
}

Diterima: 5 Januari 2017

Disetujui: 15 Februari 2017

\begin{abstract}
Hydroponic is a technology of growing plant without soil; media used are water and nutrient. Hydroponic could be classified as Aeroponic, Nutrient Film Technique (NFT), Drip Irrigation, Fertigation, and Wick System. NFT system with fertigation aspect was used in this research. Using this system, plant's roots were placed in a shallow water layer which circulated 24 hours and contain nutrient based on plant requirement. Objective of this research was to analyze uniformity on NFT hydroponic application based on slope of the pipe. Method used in this research was experimental method by experiment in the field. Observed research parameters were irrigation uniformity, Electrical Conductivity (EC), and pH of nutrient solution. Slopes used in this research were 2\%, 4\%, and 6\%. Result showed that average value of irrigation uniformity for each treatment was respectively $99.49 \%$, $99.72 \%$, and $99.27 \%$. Average value of EC was respectively $99.37 \%, 99.29 \%$ and $99.25 \%$. Whereas for pH of nutrient solution was respectively $99.04 \%, 99.27 \%$ and $99.22 \%$. From this uniformity test it can be determined that all parameters in all treatments showed uniformity.
\end{abstract}

Keywords: fertigation, hydroponic, uniformity, NFT

\begin{abstract}
ABSTRAK
Hidroponik merupakan teknologi bercocok tanam tanpa tanah dengan media yang digunakan adalah air dan nutrisi. Hidroponik dibagi menjadi beberapa system, yaitu sistem hidroponik aeroponik, NFT (Nutrient Film Technique), irigasi tetes, sistem fertigasi dan sistem wick. Pada penelitian ini digunakan sistem hidroponik NFT (Nutrient Film Technique) dengan aspek fertigasi. NFT (Nutrient Film Technique) aspek fertigasi merupakan sistem hidroponik dengan meletakkan akar tanaman pada lapisan air yang dangkal dan air tersebut tersirkulasi selama 24 jam serta mengandung nutrisi sesuai kebutuhan tanaman. Tujuan dari penelitian ini adalah menganalisis keseragaman sistem fertigasi pada aplikasi hidroponik NFT (Nutrient Film Technique) berdasarkan kemiringan talang. Metode penelitian yang digunakan adalah metode eksperimental dengan percobaan di lapangan. Adapun parameter penelitian yang diamati adalah keseragaman irigasi, keseragaman konduktivitas listrik, dan pH larutan nutrisi. Kemiringan yang digunakan pada penelitian ini adalah 2\%,4\% dan 6\%. Dari hasil penelitian didapatkan nilai rata-rata keseragaman irigasi pada ketiga perlakuan tersebut berturut-turut 99,49\%; 99,27\%; dan 99,27\%. Nilai rata-rata keseragaman konduktivitas listrik berturut-turut 99,37\%; 99,29\% dan 99,25\%. Sedangkan untuk pH berturut-turut 99,04\%; 99,27\%; dan 99,22\%. Dari hasil uji keseragaman diperoleh bahwa pada ketiga perlakuan tersebut menunjukkan semua parameter memilki keseragaman.
\end{abstract}


Kata kunci: fertigasi, hidroponik, keseragaman, NFT

\section{PENDAHULUAN}

Lahan pertanian semakin sempit akibat beralihnya fungsi lahan pertanian menjadi daerah perindustrian, sehingga budidaya hidroponik dianggap tepat untuk memanfaatkan lahan yang tersedia sebaik-baiknya. Dengan sistem hidroponik dipakai berbagai media tanam seperti arang sekam, pasir, zeolit, rockwoll, gambut (peat moss) dan serbuk sabut kelapa (Prihmantoro $\mathrm{H}$. dan Y. H. Indriani, 1999).

Penurunan luasan lahan pertanian di Indonesia akibat konversi dari sektor pertanian ke sektor non pertanian menyebabkan kegiatan budidaya pertanian mengalami kendala dalam penyediaan lahan. Tentu saja hal ini berdampak buruk bagi peningkatan kuantitas produksi pertanian khususnya pangan untuk memenuhi kebutuhan masyarakat. Selain itu, degradasi lahan atau tanah yang disebabkan oleh penggunaan pupuk dan pestisida yang berlebihan juga membuat kualitas produk pertanian yang dihasilkan semakin menurun.

Menurut hasil sensus penduduk tahun 2010, jumlah penduduk Indonesia mencapai 237 juta jiwa, sedangkan jumlah penduduk pada tahun 2000 adalah berkisar 205 juta jiwa, jika dikalkulasi selama 10 tahun terakhir maka laju pertumbuhan penduduk di Indonesia adalah 1,49 persen per tahun (Anonim, 2011). Seiring dengan pertambahan jumlah penduduk maka jumlah kebutuhan bahan pangan dari hasil pertanian pun kian meningkat. Penurunan produksi pertanian berdampak buruk terhadap pemenuhan kebutuhan pangan masyarakat.

Kondisi lahan pertanian yang kian hari semakin berkurang, sementara di sisi lain pemenuhan kebutuhan pangan dari hasil pertanian semakin meningkat, mendorong sektor pertanian untuk mengatasi kendala tersebut dengan meningkatkan penerapan pertanian lahan sempit. Berkaitan dengan hal ini, kegiatan produksi tanaman pangan di Indonesia hingga saat ini sudah relatif berkembang dimana sudah banyak digunakan teknologi budidaya yang berhasil diadopsi dari negara-negara maju. Diantaranya sistem pertanian lahan sempit yang saat ini diterapkan adalah sistem budidaya secara hidroponik. Menurut Astuti dkk (2016), hidroponik merupakan teknik budidaya tanaman tanpa menggunakan media tanah, melainkan menggunakan air sebagai media tanamnya.

Sistem hidroponik yang dilakukan tanpa menggunakan media tanah dapat menjadi solusi alternatif untuk efisiensi penggunaan lahan. Selain itu, pada sistem hidroponik pengaruh dari kondisi lingkungan pertanaman yang tidak ideal dapat diminimalisir, sesuai dengan pernyataan Sundstrom (1982) dalam Wijayani A. dan Widodo W. (2005), bahwa dengan sistem hidroponik dapat diatur kondisi lingkungan seperti suhu, kelembaban relatif dan intensitas cahaya, bahkan faktor curah hujan dapat dihilangkan sama sekali dan serangan hama penyakit dapat diperkecil. Sistem hidroponik juga menjadi solusi menghadapi kendala degradasi tanah di lahan pertanian yang semakin berkurang kesuburannya, hal ini dikarenakan pada sistem hidroponik hara disediakan dalam bentuk larutan hara, mengandung semua unsur hara esensial yang dengan meramu sendiri berbagai garam kimia.

Budidaya secara hidroponik memiliki tingkat kesukaran dalam proses pengolahannya. Selain itu, banyak hal-hal yang harus diperhatikan dalam bercocok tanam secara hidroponik seperti kualitas air, larutan nutrisi, nilai EC (Electrical Conductivity), $\mathrm{pH}$ larutan nutrisi, debit aliran air, kemiringan talang, media tanam dan lain-lain. Dalam proses budidaya hidroponik keseragaman pada setiap kemiringan sangat diperhitungkan untuk mendapatkan hasil yang maksimal. Keseragaman sangat penting pada sistem hidroponik NFT terutama dalam budidaya hidroponik skala besar.

Nutrient film technique (NFT) dengan aspek fertigasi termasuk cara baru bercocock tanam secara hidroponik. Pada sistem ini, sebagian akar tanaman terendam dalam air yang sudah mengandung pupuk dan sebagian lagi berada di atas permukaan air yang bersirkulasi selama 24 jam secara terus menerus. Lapisan air ini sangat tipis sekitar $3 \mathrm{~mm}$, sehingga mirip film. Oleh karena itulah, teknik ini disebut NFT.Beragan tanaman dapat diusahakan dengan sistem ini. Salah satu kelebihan sistem ini ialah memungkinkan tanaman dapat berproduksi sepanjang tahun (Untung O., 2000).

Dalam sistem hidroponik Nutrient film technique (NFT), air dialirkan kedalam akar 
tanaman secara dangkal. Akar tanaman berada di lapisan dangkal yang mengandung nutrisi sesuai dengan kebutuhan tanaman. Perakaran dapat berkembang didalam nutrisi dan sebagian lainnya berkembang diatas permukaan larutan. Aliran air sangat dangkal, jadi bagian atas perakaran berkembang diatas air yang meskipun lembab tetap berada di udara. Di sekeliling perakaran itu terdapat selapis larutan nutrisi (Chadirin, 2001).

Aplikasi sistem hidroponik NFT (Nutrient Film Technique) dengan aspek fertigasi pada penelitian ini bertujuan untuk Menganalisis aplikasi hidroponik NFT (Nutrient Film Technique) dengan aspek fertigasi berdasarkan kemiringan talang. Menurut Sapto Wibowo dan Arum Asriyanti S (2013), dari hasil penelitian pada tanaman sayuran (pakcoy) diperoleh dengan metode Nutrient film technique (NFT) dengan aspek fertigasi yang tinggi terdapat pada kemiringan talang 5\%. Dalam penelitian ini kemiringan pipa talang dalam konstruksi hidroponik NFT yang diterapkan besarnya yaitu $2 \%, 4 \%$ dan $6 \%$.

Berdasarkan uraian di atas maka dilakukan penelitian yang berjudul "Analisis Keseragaman Aspek Fertigasi pada Desain Sistem Hidroponik dengan Perlakuan Kemiringan Talang".

Menganalisis keseragaman aplikasi hidroponik NFT (Nutrient Film Technique) dengan sistem fertigasi berdasarkan kemiringan talang.

\section{METODE PENELITIAN}

Penelitian ini dilaksanakan di kebun petani, Bapak Jonar Siahaan, dalam suatu rumah kaca (greenhouse). Waktu penelitian dilakukan dari 08 Maret sampai dengan 04 April 2016. Alatalat yang digunakan dalam penelitian ini, yaitu sistem jaringan mikroirigasi NFT (konstruksi NFT, talang, selang plastik, pipa PVC/ jaringan perpipaan), drum nutrisi, termometer bola kering dan basah, EC meter, pH meter, gelas ukur, alat tulis, kamera, penggaris, meteran, kalkulator, stopwatch, komputer, pompa, pengaduk larutan, styrofoam, netpot, gelas ukur, dan timbangan. Bahan-bahan yang digunakan pada penelitian ini adalah larutan nutrisi, yaitu pupuk makro dan mikro yakni pupuk $\mathrm{AB}$ mix, bibit tanaman sayuran pakcoy (Brassica rapa L.).

\section{Tahapan Penelitian}

1. Dirancang konstruksi hidroponik NFT dengan ukuran dan ketentuan yang telah ditetapkan yaitu sebagai berikut:

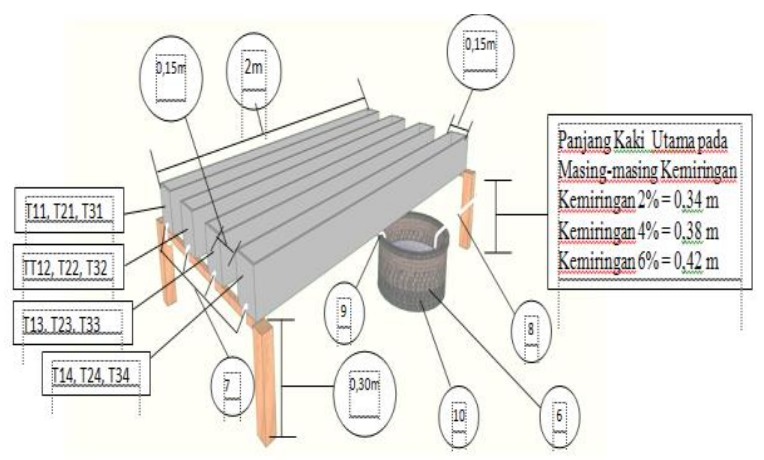

Gambar 1. Konstruksi hidroponik nft

1. Panjang Talang $=2 \mathrm{~m} \quad$ 6. Bak Nutrisi

2. Panjang Kaki Utama $=0,34 \mathrm{~m}$ 7. Saluran Outlet

3. Panjang Kaki ke-2 $=0,30 \mathrm{~m}$ 8. Pipa Inlet untuk semua Kemiringan 9. Pipa Outlet

4. Jarak talang satu ke alang lain $=0,15 \mathrm{~m}$ 10. Pompa Air Skala

5. Lebar Talang $=0,15 \mathrm{~m}$

T11. Talang Kemiringan 2\% ke 1 T21: Talang Kemiringan 4\% ke 1 T31: Talang Kemiringan $6 \%$ ke 1 T12: Talang Kemiringan 2\% ke 2 T22: Talang Kemiringan 4\% ke 2 T32: Talang Kemiringan 6\% ke 2 T13: Talang Kemiringan $2 \%$ ke 3 T23: Talang Kemiringan 4\% ke 3 T33: Talang Kemiringan $6 \%$ ke 3 T14: Talang Kemiringan $2 \%$ ke 4 T24: Talang Kemiringan $4 \%$ ke 4 T34: Talang Kemiringan 6\% ke 4

2. Diletakkan drum nutrisi pada posisi sejajar dengan ketinggian minimum dari ujung outlet talang.

3. Dipasang pipa lateral yang dilengkapi selang plastik sebagai inlet pada drum nutrisi.

4. Dipasang pipa penampung dengan posisi miring yang dilengkapi dengan selang plastik sebagai outlet.

5. Pada salah satu kaki atap diletakkan termometer bola kering dan bola basah.

\section{Parameter Penelitian}

\section{Perhitungan Keseragaman Irigasi}

Sapei, A. (2003) menyatakan bahwa nilai CU (Coefficient Uniformity) haruslah lebih besar dari $80 \%$. Nilai CU yang rendah dapat dijadikan indikator bahwa banyak kehilangan air dan nilai efektifitas yang rendah.

Menurut Michael A.M. (2001) bahwa keseragaman aplikasi air (Coefficient Uniformity) merupakan salah satu penentu dalam efisiensi irigasi yang dihitung dengan persamaan koefisien keseragaman irigasi (CU/ Coefficient Uniformity) dengan rumus: 
Dimana:

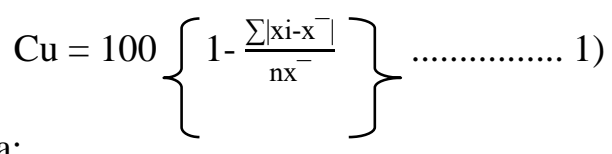

$\mathrm{Cu}=$ Koefisien keseragaman irigasi $(\%)$

$\mathrm{n}=$ Jumlah outlet

$\overline{\mathrm{X}}=$ Nilai rata-rata dari debit air pada tiap outlet

xi = Volume pemakaian air pada tiap talang kei

$\sum\left|\mathrm{xi}^{-} \mathrm{x}^{-}\right|=$Jumlah dari deviasi absolut dari ratarata pengukuran $(\mathrm{ml} / \mathrm{s})$

\section{Keseragaman konduktivitas listrik (EC)}

Keseragaman konduktivitas listrik (EC) ditentukan juga dengan menyesuaikan variabel yang akan dihitung.

Dimana :

$$
\mathrm{Cu}=100\left\{1-\frac{\sum\left|\mathrm{xi}^{-}-\right|}{n \mathrm{x}^{-}}\right\}
$$

$\mathrm{Cu}=$ Koefisien keseragaman konduktivitas listrik $(\%)$

$\mathrm{n} \quad=$ Jumlah outlet

$\overline{\mathrm{x}} \quad=$ Nilai rata-rata dari konduktivitas listrik tiap outlet $(\mathrm{mS} / \mathrm{cm})$

$\mathrm{xi}=$ Konduktivitas listrik pada tiap talang ke-i $\sum\left|\mathrm{xi}^{-} \mathrm{x}^{-}\right|=$Jumlah dari deviasi absolut dari ratarata pengukuran $(\mathrm{mS} / \mathrm{cm})$.

\section{Keseragaman pH Larutan Nutrisi}

Keseragaman $\mathrm{pH}$ larutan nutrisi ditentukan jugadengan menyesuaikan variabel yang dihitung.

$$
\mathrm{Cu}=100\left\{1-\frac{\sum\left|\mathrm{xi}_{-\mathrm{x}}^{-}\right|}{\mathrm{nx}^{-}}\right\}
$$

Dimana :

$\mathrm{Cu}=$ Koefisien keseragaman $\mathrm{pH}$ Larutan $(\%)$

$\mathrm{n}=$ Jumlah outlet

$\overline{\mathrm{x}}=$ Nilai rata-rata dari debit air pada tiap outlet

xi $=$ Volume pemakaian air pada tiap talang ke-i

$\sum\left|\mathrm{xi}^{-} \mathrm{x}^{-}\right|=$Jumlah dari deviasi absolut dari ratarata $\mathrm{pH}$ larutan

4. Hubungan suhu lingkungan terhadap Electrical Conductivity (EC)/konduktivitas listrik
5. Hubungan antara nilai Electrical Conductivity $(E C) /$ konduktivitas listrik larutan dengan jumlah Pupuk yang dilarutkan dalam 25 liter air

6. Hubungan suhu air dengan suhu lingkungan

\section{Evaluasi talang}

\section{Prosedur Penelitian}

Adapun prosedur penelitian adalah sebagai berikut (Gambar 2):

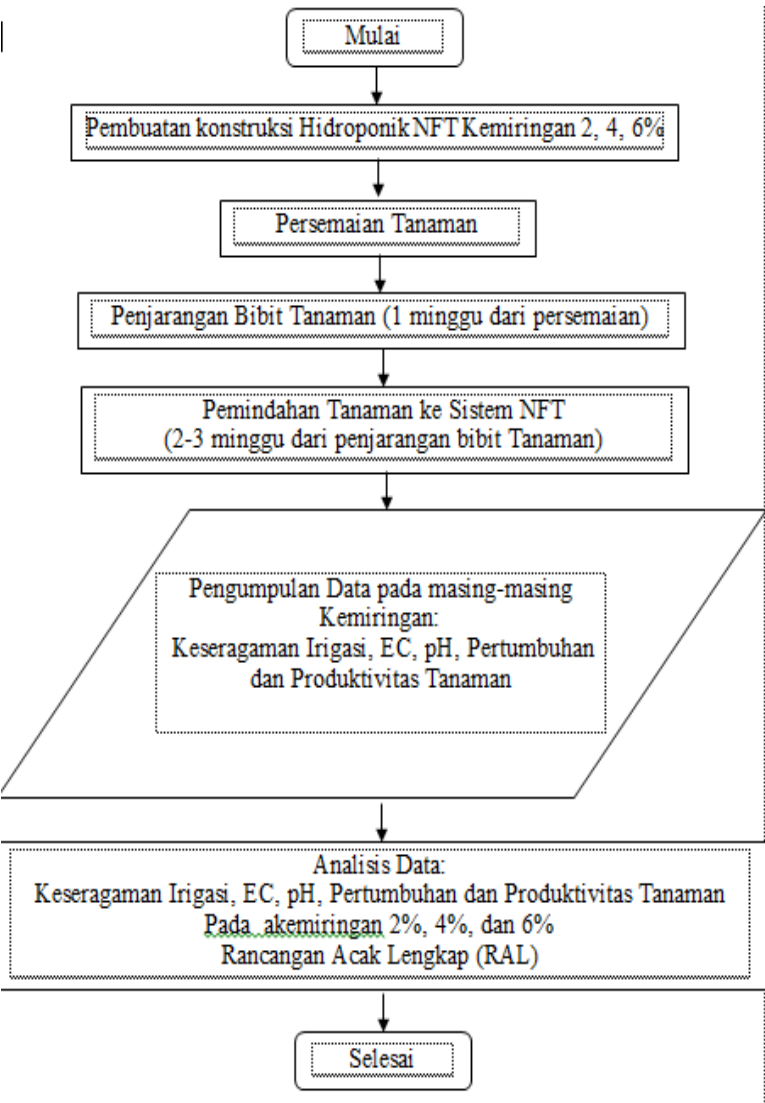

Gambar 2. Diagram alir penelitian

1. Drum diisi larutan nutrisi dengan $\mathrm{EC}$ dan $\mathrm{pH}$ yang tepat lalu diaduk secara manual sampai larutan tercampur merata

2. Pengaduk diaktifkan untuk mengaduk larutan nutrisi agar tercampur merata

3. Pompa diaktifkan agar nutrisi mengalir di dalam talang

4. Dilakukan pemindahan tanaman dari persemaian ke media tanam 
5. Dilakukan pengamatan pada setiap hari sampai tanaman dapat dipanen selama 28 hari.

\section{Pelaksanaan Persemaian}

1. Disediakan persemaian dengan menggunakan media rockwall

2. Ditanam benih dengan jarak tanam $1 \mathrm{~cm} \times 1$ $\mathrm{cm}$

3. Persemaian diberi naungan

4. Setelah bibit pakcoy berdaun 3-4 helai pakcoy dapat dipindah ke talang.

\section{Pengambilan Data}

Adapun data-data yang dikumpulkan pada penelitian ini adalah sebagai berikut:

1. Data suhu harian

Pengukuran data suhu harian pada setiap hari selama pertumbuhan tanaman yang dilakukan pada pukul 07.00, 13.30 dan 17.30 menggunakan termometer bola kering dan bola basah.

2. Data sekunder iklim setempat

Pengumpulan data sekunder iklim setempat yang meliputi data persentase jam untuk wilayah Mataram.

3. Nilai EC dan $\mathrm{pH}$ pada seluruh tanaman

Pengukuran nilai EC dan $\mathrm{pH}$ pada seluruh tanaman selama periode pertumbuhan pada pukul 17.00 WITA untuk setiap hari.

4. Suhu larutan pada setiap outlet

Pengukuran suhu larutan pada setiap outlet untuk masing-masing kemiringan talang yang berbeda pada pukul 13.30 pada hari ke- 4,14 dan 28.

5. Nilai EC larutan dan $\mathrm{pH}$ larutan pada setiap outlet

Pengukuran nilai EC pada setiap outlet untuk masing-masing kemiringan talang pada pukul 17.30 WITA setiap hari untuk mengetahui perubahan EC terhadap temperatur lingkungan.

6. Besar debit tiap inlet dan outlet

Pengukuran besarnya debit pada hari ke-4, 14 dan 28 pada pukul 12.00 WITA.

7. Nilai EC dan $\mathrm{pH}$ larutan pada satu outlet talang Pengukuran nilai EC dan $\mathrm{pH}$ larutan pada satu outlet talang untuk masing-masing metode aplikasi pemberian larutan nutrisi pada setiap jam sepanjang hari pukul 06.00-18.00 WITA pada hari ke-14 untuk mengetahui perubahan
EC dan $\mathrm{pH}$ larutan terhadap temperatur dan kelembaban lingkungan.

\section{HASIL DAN PEMBAHASAN}

\section{Keseragaman Debit Irigasi, Konduktivitas Listrik (EC) dan pH larutan Nutrisi Keseragaman Debit Outlet}

Besarnya nilai keseragaman debit outlet setiap periode pertumbuhan dapat dilihat pada tabel 1 .

Tabel 1. Nilaikeseragaman debit outlet pada setiap period pertumbuhan tanaman pakcoy

\begin{tabular}{cccc}
\hline Periode & \multicolumn{3}{c}{ Keseragaman Debit Outlet (\%) } \\
\cline { 2 - 4 } Pertumbuhan & \multicolumn{3}{c}{ Kemiringan } \\
\cline { 2 - 4 } & $2 \%$ & $4 \%$ & $6 \%$ \\
\hline Awal & 98,85 & 99,46 & 98.95 \\
Tengah & 99,76 & 99,08 & 98,97 \\
Akhir & 99,87 & 99,93 & 99,89 \\
\hline
\end{tabular}

Periode awal pertumbuhan $\quad: 4$ hari setelah pindah tanam Periode tengah pertumbuhan $\quad: 14$ hari setelah pindah tanam Periode akhir pertumbuhan $\quad: 28$ hari setelah pindah tanam

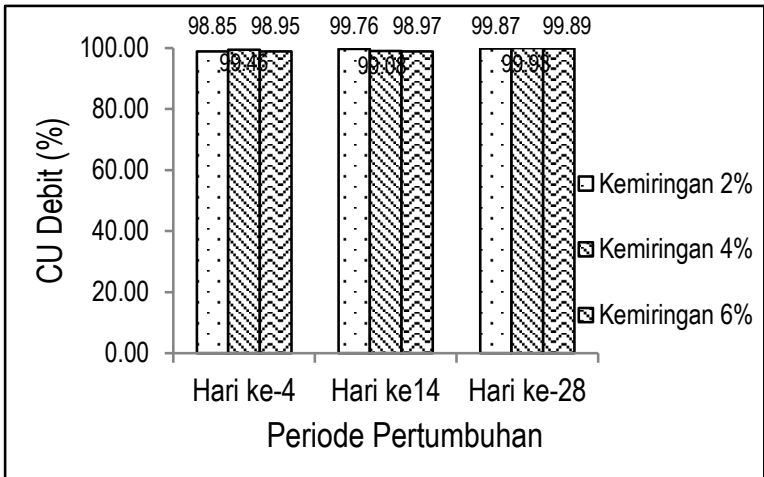

Gambar 3. Diagram keseragaman debit outlet dalam setiap fase pertumbuhan

Nilai keseragaman debit outlet merupakan nilai yang diperoleh dengan pengukuran debit outlet setiap talang pada awal, tengah dan akhir pertumbuhan tanaman. Pada tabel dan diagram di atas menunjukkan bahwa nilai keseragaman debit outlet pada talang selama awal, tengah dan akhir pertumbuhan menunjukkan lebih dari $80 \%$. Sesuai dengan Sapei (2003), hal ini menunjukkan bahwa jaringan irigasi hidroponik NFT mampu memberikan distribusi larutan yang cukup merata untuk masing-masing perlakuan. 
Debit larutan nutrisi pada ketiga perlakuan tersebut cenderung mengalami penurunan untuk setiap periode pertumbuhan dapat di lihat pada Lampiran 5. Hal ini sesuai dengan (Untung, 2000) yang mengatakan jika akar tanaman semakin banyak kecepatan aliran nutrisi otomatis semakin berkurang. Pertumbuhan akar tanaman dalam setiap periode pertumbuhan akan mengakibatkan kecepatan aliran nutrisi semakin berkurang. Sehingga kecepatan aliran nutrisi akan mengakibatkan ketebalan nutrisi tersebut berubah selama periode pertumbuhan tanaman pakcoy tersebut.

Debit outlet yang terbesar terdapat pada awal pertumbuhan sedangkan debit outlet yang teredah terdapat pada akhir pertumbuhan tanaman untuk masing-masing kemiringan talang. Yang membedakan mengapa debit outlet pada awal pertumbuhan tanaman memiliki nilai terbesar selain disebabkan oleh masing-masing kemiringan, faktor tanaman juga mempengaruhi karena akar-akar tanaman pada awal pertumbuhan masih berukuran kecil dan daya serap akar tanaman yang masih lambat. Berbeda dengan periode akhir pertumbuhan debit outlet menjadi kecil ini dipengaruhi oleh tingkat kemiringan, jumlah akar yang semakin banyak pada tanaman serta adanya lumut yang ada pada talang akan menghambat laju dari air tersebut.

\section{Debit Inlet dan Outlet pada Masing-masing} Kemiringan

Tabel 2. Debit inlet pada masing-masing kemiringan

\begin{tabular}{|c|c|c|c|c|c|c|c|c|c|c|c|c|}
\hline \multirow{3}{*}{ Hari } & \multicolumn{4}{|c|}{ Keniringan 2\% } & \multicolumn{4}{c|}{ Kemiringan 4\% } & \multicolumn{4}{c|}{ Kemiringan $6 \%$} \\
\cline { 2 - 13 } & T11 & T12 & T13 & T14 & T21 & T22 & T23 & T24 & T31 & T32 & T33 & T34 \\
\hline 4 & 16.39 & 16.33 & 16.19 & 16.99 & 17.01 & 17 & 17.45 & 17.03 & 16.69 & 16.59 & 16.17 & 16.45 \\
\hline 14 & 15.87 & 16.14 & 15.58 & 16.59 & 15.44 & 15.67 & 15.58 & 16.43 & 14.65 & 14.53 & 14.74 & 14.75 \\
\hline 28 & 15.41 & 15.65 & 15.39 & 15.43 & 15.27 & 15.23 & 15.27 & 15.36 & 15.21 & 15.25 & 15.28 & 15.3 \\
\hline
\end{tabular}

Tabel 3. Data debit outlet masing-masing kemiringan

\begin{tabular}{|c|c|c|c|c|c|c|c|c|c|c|c|c|}
\hline \multirow{2}{*}{ Hari } & \multicolumn{4}{|c|}{ Kemiringan 2\% } & \multicolumn{4}{c|}{ Kemiringan 4\% } & \multicolumn{4}{c|}{ Kemiringan 6\% } \\
\cline { 2 - 14 } & T11 & T12 & T13 & T14 & T21 & T22 & T23 & T24 & T31 & T32 & T33 & T34 \\
\hline 4 & 8.59 & 8.33 & 8.3 & 8.37 & 9.68 & 9.64 & 9.73 & 9.8 & 14.71 & 14.68 & 14.3 & 14.48 \\
\hline 14 & 7.67 & 7.7 & 7.67 & 7.63 & 7.95 & 7.88 & 7.98 & 7.76 & 9.19 & 9.41 & 9.5 & 9.43 \\
\hline 28 & 7.55 & 7.53 & 7.54 & 7.52 & 7.65 & 7.66 & 7.64 & 7.65 & 8.97 & 8.98 & 8.96 & 8.99 \\
\hline
\end{tabular}

Pada Tabel 2 dan 3 menunjukkan bahwa debit larutan nutrisi pada ketiga perlakuan tersebut cenderung mengalami penurunan dari periode awal (hari ke-4), tengah (hari ke-14), dan akhir (hari ke-28) pertumbuhan tanaman. Hal ini sesuai dengan (Untung, 2000) yang mengatakan jika akar tanaman semakin banyak kecepatan aliran nutrisi otomatis semakin berkurang. Pertumbuhan akar tanaman dalam setiap periode pertumbuhan akan mengakibatkan kecepatan aliran nutrisi semakin berkurang. Sehingga kecepatan aliran nutrisi akan mengakibatkan ketebalan nutrisi tersebut berubah selama periode pertumbuhan tanaman pakcoy tersebut.

Tabel debit inlet dan outlet menunjukkan bahwa debit inlet dan outlet yang terbesar terdapat pada awal pertumbuhan sedangkan debit inlet dan outlet yang teredah terdapat pada akhir pertumbuhan tanaman untuk masing-masing kemiringan yakni kemiringan 2\%, 4\% dan $6 \%$. Yang membedakan mengapa debit inlet dan outlet pada awal pertumbuhan tanaman memiliki nilai terbesar ini disebabkan selain oleh kemiringan, faktor tanaman juga mempengaruhi karena akarakar tanaman pada awal pertumbuhan masih berukuran kecil dan daya serap akar tanaman yang masih lambat. Berbe da dengan periode akhir pertumbuhan debit inlet dan outlet menjadi kecil ini dipengaruhi oleh tingkat kemiringan, jumlah akar yang semakin banyak pada tanaman serta adanya lumut yang ada pada talang dan pompa yang akan menghambat laju dari air tersebut.

Debit larutan berpengaruh terhadap pertumbuhan tanaman ini disebabkan karena aliran air yang terlalu deras akan menghambat proses pertumbuhan tanaman ini menyebabkan akar tanaman akan sulit untuk menyerap unsur hara yang terdapat pada air tersebut. Maka faktor kemiringan menjadi salah satu pertimbangan dalam proses pembuatan kemiringan talang yang sesuai untuk tanaman agar tanaman dapat tumbuh secara normal.

\section{Keseragaman Electrical Conductivity (EC)/ konduktivitas listrik}

Keseragaman konduktivitas listrik diperoleh dengan menggunakan persamaan (2). Besarnya nilai keseragaman konduktivitas listrik setiap periode pertumbuhan disajikan pada Tabel 4 dan Gambar 4. 
Tabel 4. Nilai Keseragaman Konduktivitas Listrik pada Setiap Periode Pertumbuhan

\begin{tabular}{cccc}
\hline \multirow{2}{*}{$\begin{array}{c}\text { Periode } \\
\text { Pertumbuhan }\end{array}$} & \multicolumn{3}{c}{$\begin{array}{c}\text { Keseragaman Konduktivitas Listrik } \\
(\%)\end{array}$} \\
\cline { 2 - 4 } & \multicolumn{3}{c}{ Kemiringan } \\
\cline { 2 - 4 } & $2 \%$ & $4 \%$ & $6 \%$ \\
\hline Awal & 99.50 & 99.25 & 99.50 \\
Tengah & 99.63 & 99.50 & 99.50 \\
Akhir & 99.50 & 99.63 & 99.63 \\
\hline
\end{tabular}

Periode awal pertumbuhan $: 0-9$ hari setelah pindah tanam Periode tengah pertumbuhan : 10 - 18 hari setelah pindah tanam Periode akhir pertumbuhan : $19-28$ hari setelah pindah tanam

Hasil perhitungan keseragaman konduktivitas listrik disajikan dalam Gambar 4.

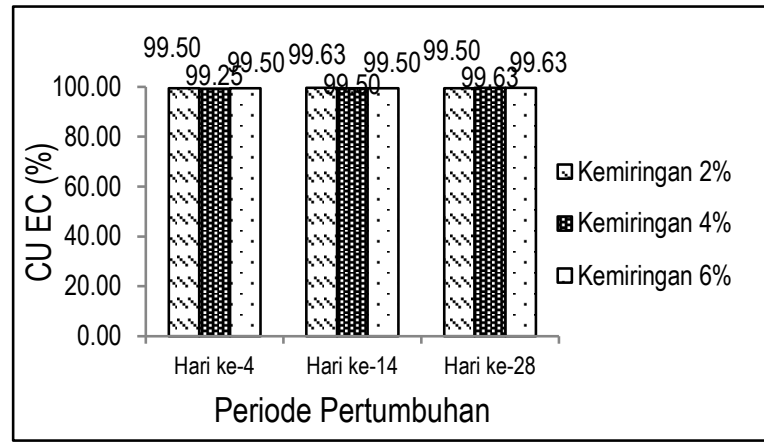

Gambar 4. Diagram Keseragaman

Konduktivitas Listrik Nutrisi dalam Setiap Fase Pertumbuhan

Electrical Conductivity (EC)/ konduktivitas listrik merupakan suatu kemampuan air sebagai penghantar listrik yang dipengaruhi oleh jumlah ion atau garam yang terlarut dalam air dengan satuan $\mathrm{mS} / \mathrm{cm}$. Semakin banyak garam yang terlarut, semakin tinggi daya hantar listrik yang terjadi (Susila, 2006). Keseragaman Electrical Conductivity (EC)/konduktivitas listrik larutan adalah keseragaman dari variasi nilai Electrical Conductivity (EC)/konduktivitas listrik larutan nutrisi pada setiap outlet untuk ketiga kemiringan, yakni kemiringan $2 \%, 4 \%$ dan $6 \%$. Kunci utama dalam pemberian larutan nutrisi atau pupuk pada sistem hidroponik adalah pengontrolan Electrical Conductivity (EC)/konduktivitas listrik atau aliran listrik di dalam air dengan menggunakan alat EC meter. Electrical Conductivity (EC)/konduktivitas listrik digunakan untuk mengetahui cocok tidaknya larutan nutrisi untuk tanaman. Setiap tanaman memiliki nilai Electrical Conductivity
(EC)/konduktivitas listrik yang berbeda-beda untuk pertumbuhannya.

Semakin tinggi garam yang terdapat dalam air, semakin tinggi pula nilai Electrical Conductivity (EC)/konduktivitas listriknya. Konsentrasi garam yang tinggi dapat merusak akar tanaman dan mengganggu serapan nutrisi dan air (Hochmuth, 1991). Setiap jenis dan umur tanaman membutuhkan larutan dengan Electrical Conductivity (EC)/konduktivitas listrik yang berbeda-beda. Kebutuhan Electrical Conductivity (EC)/konduktivitas listrik disesuaikan dengan fase pertumbuhan, yaitu ketika tanaman masih kecil, Electrical Conductivity (EC)/konduktivitas listrik yang dibutuhkan juga kecil. Semakin meningkat umur tanaman semakin besar Electrical Conductivity (EC)/konduktivitas listriknya.

Pada Tabel 4 dan Gambar 4 menunjukkan bahwa nilai keseragaman Electrical Conductivity (EC)/konduktivitas listrik untuk ketiga aplikasi sudah lebih besar dari $80 \%$. Sesuai dengan Sapei (2003) hal ini menunjukkan bahwa larutan nutrisi untuk ketiga kemiringan talang terdistribusi secara baik. Nilai keseragaman Electrical Conductivity (EC)/konduktivitas listrik pada setiap talang sangat penting untuk pertumbuhan tanaman. Semakin tinggi nilai keseragaman Electrical Conductivity (EC)/konduktivitas listrik maka semakin bagus untuk pertumbuhan tanaman. Begitu sebaliknya semakin rendah nilai keseragaman Electrical Conductivity (EC)/konduktivitas listrik maka pertumbuhan tanaman akan terhambat.

Perbedaan keseragaman Electrical Conductivity (EC)/konduktivitas listrik tidak berbeda jauh antara tiga kemiringan yakni $2 \%, 4 \%$ dan $6 \%$ dapat dilihat pada Tabel 5. Nilai keseragaman tersebut dipengaruhi oleh nilai Electrical Conductivity (EC)/konduktivitas listrik yang terukur. Pada diagram diatas menunjukkan bahwa pada kemiringan $4 \%$ memiliki nilai keseragaman yang relatif tinggi dibandingkan dengan kemiringan 2\% dan 6\%. Ini menunjukkan kemiringan $4 \%$ sesuai untuk digunakan sebagai sistem hidroponik NFT (Nutrient Film Technique) aspek fertigasi. Keseragaman Electrical Conductivity (EC)/konduktivitas listrik sangat penting digunakan dalam budidaya hidroponik dalam skala besar untuk meningkatkan produksi. 
Nilai keseragaman pada Electrical Conductivity (EC)/konduktivitas listrik perlu diseragamkan dengan tujuan untuk memberikan nilai unsur hara yang cocok untuk pertumbuhan tanaman. Nilai keseragaman yang merata sangat penting pada budidaya tanaman sayuran terutama dalam sistem hidroponik NFT (Nutrient Film Technique) aspek fertigasi skala besar untukmendapatkan hasil pertumbuhan tanaman yang merata.

\section{Nilai Rata-rata Electrical Conductivity (EC)/konduktivitas listrik pada masing- masing kemiringan}

Tabel 5. Data Nilai Rata-rata Electrical Conductivity

(EC)/konduktivitas listrik pada masing-masing kemiringan

\begin{tabular}{|c|c|c|c|c|c|c|c|c|c|c|c|c|}
\hline \multirow{2}{*}{ Hari } & \multicolumn{4}{|c|}{ Kemiringan 2\% } & \multicolumn{4}{c|}{ Kemiringan 4\% } & \multicolumn{4}{c|}{ Kemiringan 6\% } \\
\cline { 2 - 14 } & T11 & T12 & T13 & T14 & T21 & T22 & T23 & T24 & T31 & T32 & T33 & T34 \\
\hline $1-4$ & 1.39 & 1.41 & 1.40 & 1.41 & 1.39 & 1.4 & 1.39 & 1.4 & 1.46 & 1.47 & 1.46 & 1.46 \\
\hline $5-14$ & 1.89 & 1.89 & 1.88 & 1.89 & 1.8 & 1.79 & 1.8 & 1.81 & 1.89 & 1.89 & 1.89 & 1.89 \\
\hline $15-28$ & 3.13 & 3.13 & 3.12 & 3.13 & 3.1 & 3.09 & 3.09 & 3.09 & 3.14 & 3.13 & 3.14 & 3.13 \\
\hline
\end{tabular}

Pada Tabel 5 menunjukkan hasil pengukuran nilai Electrical Conductivity (EC)/konduktivitas listrik setiap periode pertumbuhan tanaman. Pada tabel di atas menunjukkan bahwa nilai Electrical Conductivity (EC)/konduktivitas listrik terus meningkat setiap hari dalam satu periode pertumbuhan dapat dilihat pada Lampiran 5. Hal ini disebabkan karena penambahan materi organik dan mikroorganisme di dalam larutan nutrisi dan juga diakibatkan akar yang mati dan melapuk ikut tercuci ke dalam larutan nutrisi. Selain itu, perubahan suhu lingkungan juga dapat mempengaruhi Electrical Conductivity (EC)/konduktivitas listrik. Hal ini sesuai dengan (Karsono, dkk, 2002) yang menyatakan bahwa temperatur tinggi mengakibatkan reaksi kimia semakin cepat. Peningkatan suhu akan mengakibatkan reaksi kimia dalam larutan semakin cepat dan pergerakan ion-ion dalam larutan aktif dan cepat. Peningkatan ini akan megakibatkan nilai Electrical Conductivity (EC)/konduktivitas listrik semakin meningkat.

$$
\text { Angka Electrical Conductivity }
$$

(EC)/konduktivitas listrik sangat penting di dalam hidroponik sistem NFT karena berdasarkan angka inilah produktivitas tanaman bisa dipacu. Untuk tanaman kecil/belum dewasa, angka Electrical Conductivity (EC)/konduktivitas listrik berkisar antara 1-1,5 $\mathrm{mS} / \mathrm{cm}$. Setelah dewasa atau menjelang berbunga/berbuah, Electrical Conductivity (EC)/konduktivitas listrik bisa ditingkatkan sampai 2,5-4 mS/cm, kecuali untuk tomat yang Electrical Conductivity (EC)/konduktivitas listriknya bisa sampai 7. Pada umumnya, angka Electrical Conductivity (EC)/konduktivitas listrik lebih dari 4 akan menimbulkan toksisitas pada tanaman (Untung, 2000). Apabila melebihi dari yang telah ditetapkan, maka pertumbuhan tanaman akan menjadi sulit bahkan mengakibatkan kematian pada tanaman. Setiap tanaman memiliki standar nilai Electrical Conductivity (EC)/konduktivitas listrik yang berbeda-beda. Untuk mendapatkan nilai Electrical Conductivity (EC)/konduktivitas listrik yang sesuai maka perlu diperhatikan penggunaan air, nutrisi yang digunakan. Air yang baik untuk pertumbuhan tanaman adalah air murni seperti air sumur, PDAM, dan air hujan. Sedangkan air sungai tidak bisa digunakan karena air tersebut sudah tercampur dari berbagai macam sumber dan tentunya sudah merusak susunan kimia dari air tersebut.

Nilai Electrical Conductivity (EC)/konduktivitas listrik dipengaruhi oleh tingkat kepekatan dari konsentrasi kation dan anion. Semakin pekat konsentrasi kation dan anion maka semakin tinggi nilai Electrical Conductivity (EC)/konduktivitas listrik larutan. Begitupula dengan penambahan materi-materi dalam larutan menambah besarnya padatan yang terlarut di dalam larutan nutrisi tersebut. Sehingga nilai Electrical Conductivity (EC)/konduktivitas listrik larutan nutrisi semakin meningkat dalam setiap periode pertumbuhan tanaman (Sutiyoso, 2003).

\section{Keseragaman pH Larutan Nutrisi}

Keseragaman $\mathrm{pH}$ larutan nutrisi diperoleh dengan menggunakan persamaan 3. Besarnya nilai keseragaman $\mathrm{pH}$ larutan nutrisi setiap periode pertumbuhan disajikan pada Tabel 6 dan Gambar 5. 
Tabel 6. Nilai Keseragaman $\mathrm{pH}$ Larutan Nutrisi pada Setiap Periode Pertumbuhan Tanaman Pakcoy

\begin{tabular}{|cccc|}
\hline Periode & \multicolumn{3}{c|}{ Keseragaman pH Larutan Nutrisi (\%) } \\
\cline { 2 - 4 } Pertumbuhan & Kemiringan & Kemiringan & Kemiringan \\
& $2 \%$ & $4 \%$ & $6 \%$ \\
\hline Awal & 99,00 & 99,63 & 99,50 \\
Tengah & 99,25 & 99,13 & 99,25 \\
Akhir & 99,25 & 98,88 & 99,50 \\
\hline
\end{tabular}

Nilai keseragaman $\mathrm{pH}$ larutan nutrisi dapat dilihat pada diagram berikut:

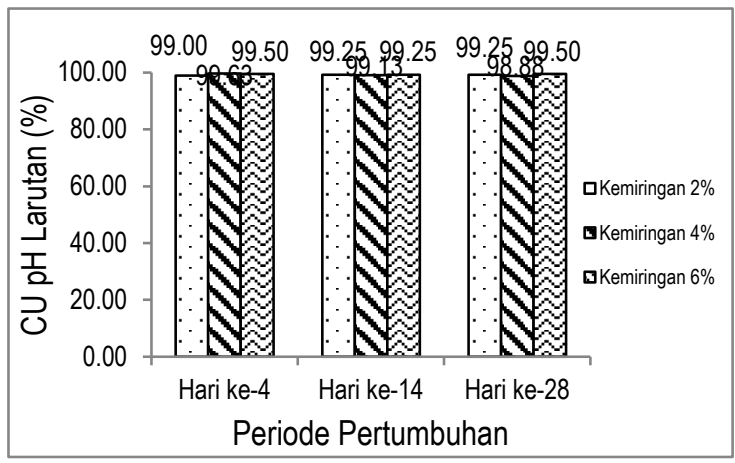

Gambar 5. Diagram Keseragaman $\mathrm{pH}$ Larutan

Nutrisi dalam Setiap Fase Pertumbuhan

Derajat keasaman $(\mathrm{pH})$ berkisar dari 0 hingga 14. Di angka 7, pH dianggap netral karena muatan listrik kation $\mathrm{H}^{+}$seimbangdengan muatan listrik anion $\mathrm{OH}^{+}$. Semakin kecil angka $\mathrm{pH}$, semakin asam kondisi larutan. Semakin besar angka $\mathrm{pH}$, semakin alkalis (basa) kondisi larutan. Kisaran pH yang disukai tanaman 5,5-7,5. Di kisaran tersebut, daya larut unsur-unsur hara dalam kondisi optimal (Karsono, dkk 2002). Air untuk NFT perlu dicek derajat keasamannya $(\mathrm{pH})$. Tinggi rendahnya angka $\mathrm{pH}$ sangat mempengaruhi daya larut unsur-unsur hara sehingga mudah diserap oleh akar.

Pada Tabel 6 dan Gambar 5 menunjukkan derajat keasaman $\mathrm{pH}$ larutan nutrisi memiliki nilai keseragaman yang tinggi. Besarnya nilai $\mathrm{CU}$ (Coefficient Uniformity) $\mathrm{pH}$ nutrisi untuk ketiga aplikasi kemiringan talang sudah lebih dari $80 \%$. Sesuai dengan Sapei (2003), hal ini menunjukkan bahwa keasaman $(\mathrm{pH})$ pada kedua talang terdistribusi secara merata.

Derajat keasaman larutan $\mathrm{pH}$ nutrisi pada ketiga aplikasi kemiringan menunjukkan nilai keseragaman yang tinggi. Semakin tinggi nilai keseragaman nutrisi maka pertumbuhan tanaman akan semakin baik begitu sebaliknya apabila nilai keseragaman derajat keasaman $\mathrm{pH}$ rendah maka tanaman akan sulit untuk tumbuh normal. Kemiringan 4\% memiliki nilai keseragaman yang tidak berbeda jauh dengan kemiringan $2 \%$ dan $6 \%$. Kemiringan $4 \%$ memiliki desain kemiringan yang sesuai untuk meningkatkan keseragaman derajat keasaman $\mathrm{pH}$ larutan nutrisi dan cocok digunakan untuk budidaya hidroponik NFT (Nutrient Film Technique) dalam skala besar.

Data Rata-rata pH Larutan Nutrisi pada
Masing-masing Kemiringan
Tabel 7. Data Rata-rata pH Larutan Nutrisi pada Masing-masing Kemiringan

\begin{tabular}{|c|c|c|c|c|c|c|c|c|c|c|c|c|c|}
\hline \multirow{2}{*}{ Hari } & \multicolumn{4}{|c|}{ Keminingan 2\% } & \multicolumn{4}{|c|}{ Kemingan 4\% } & \multicolumn{4}{c|}{ Kemingan 6\% } & Rata- \\
\cline { 2 - 13 } & T11 & T12 & T13 & T1 & TT1 & T22 & T23 & T24 & T31 & T32 & T33 & T34 & \\
\hline 1.4 & 7.36 & 7.38 & 7.37 & 7.38 & 7.16 & 7.16 & 7.17 & 7.17 & 7.36 & 7.37 & 7.36 & 7.36 & 73 \\
\hline $5-14$ & 7.23 & 7.23 & 7.23 & 7.24 & 7.42 & 7.42 & 7.42 & 7.42 & 7.28 & 7.27 & 7.28 & 7.28 & 7.31 \\
\hline $15-28$ & 6.83 & 6.82 & 6.83 & 6.84 & 6.84 & 6.83 & 6.83 & 6.83 & 6.87 & 6.87 & 6.88 & 6.87 & 6.84 \\
\hline
\end{tabular}

Data hasil pengukuran nilai $\mathrm{pH}$ larutan nutrisi dapat diilhat pada Tabel 7. Dari data pengukuran $\mathrm{pH}$ larutan nutrisi tersebut menunjukkan bahwa $\mathrm{pH}$ larutan nutrisi pada ketiga kemiringan cenderung mengalami fluktuasi pada setiap periode pertumbuhan tanaman, pada bak nutrisi dengan kapasitas 25 liter air dengan sumber air, yaitu air sumur memiliki banyak kandungan kimia yang terlarut dalam air yang tidak dapat dilihat dengan mata biasa. Untuk mengukur tingkat keasaman dari air tersebut maka perlu menggunakan alat, yaitu $\mathrm{pH}$ meter.

Hasil pengukuran menggunakan $\mathrm{PH}$ meter menunjukkan bahwa pada awal pertumbuhan tanaman untuk ketiga perlakuan air $\mathrm{pH}$ rata-rata berkisar 7,3 ; pada tengah pertumbuhan rata-rata $\mathrm{pH}$ berkisar 7,31; dan pada akhir pertumbuhan rata-rata $\mathrm{pH}$ menurun menjadi 6,84. Hal ini menunjukkan bahwa pada larutan nutrisi lebih banyak mengandung anion dibandingkan dengan kation. Kation adalah ionion yang bermuatan positif antara lain $\mathrm{NH}^{4+}, \mathrm{K}^{+}$, $\mathrm{Ca}^{2+}, \mathrm{Mg}^{2+}, \mathrm{Cu}^{2+}, \mathrm{Mn}^{2+}, \mathrm{Mo}^{2+}$, dan $\mathrm{Zn}^{2+}$. Pada periode awal dan tengah pertumbuhan tanaman lebih banyak menyerap Anion. Anion adalah ionion yang bermuatan negatif antara lain $\mathrm{NO}_{3}{ }^{-}, \mathrm{PO}_{4}{ }^{2-}$ , $\mathrm{SO}_{4}{ }^{2-}$ dan $\mathrm{BO}_{3}{ }^{3-}$. Hal ini sesuai dengan Sutiyoso (2003) yang menyatakan dalam perjalanan pertumbuhan tanaman mungkin akan ada 
perubahan $\mathrm{pH}$ atau $\mathrm{pH}$ akan mengalami naik dan turun. Misalnya pada tanaman yang masih kecil lebih banyak menyerap anion dan ketika tumbuh besar lebih banyak menyerap kation.

\section{Hubungan Suhu Lingkungan Terhadap Konduktivitas Listrik (EC)}

Pengukuran suhu lingkungan dan Electrical Conductivity (EC)/konduktivitas listrik pada salah satu outlet talang untuk masing-masing kemiringan yakni $2 \%, 4 \%$ dan $6 \%$. Data diambil setiap jam sepanjang hari dari pukul 06.00-18.00 WIT pada hari ke-14.

Hubungan suhu lingkungan dan Electrical Conductivity (EC)/konduktivitas listrik ini dilakukan untuk mengetahui apakah ada pengaruh suhu terhadap perubahan Electrical Conductivity (EC)/konduktivitas listrik.

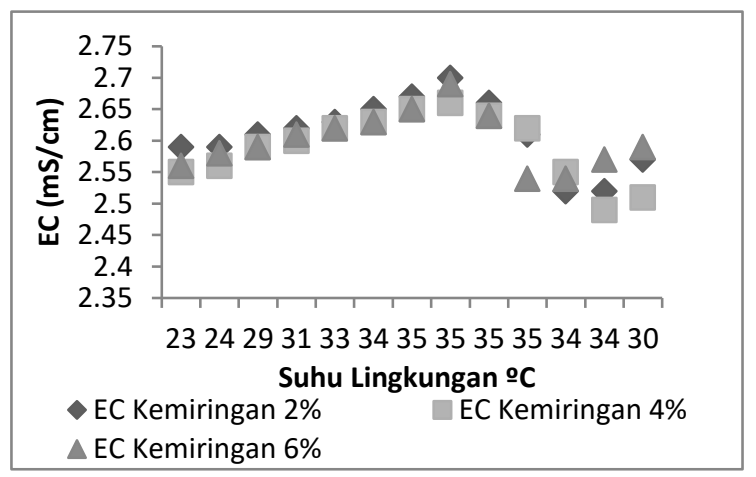

Gambar 6. Grafik Hubungan Suhu Lingkungan Terhadap Konduktivitas Listrik

Suhu lingkungan yang semakin meningkat setiap jamnya berpengaruh terhadap nilai Electrical Conductivity (EC)/konduktivitas listrik pada tiap-tiap outlet talang pada ketiga perlakuan. Untuk mengetahui hubungan suhu lingkungan dengan nilai Electrical Conductivity (EC)/konduktivitas listrik dilakukan pengamatan pada hari ke-14. Pada hari ke-14 merupakan periode tengah pertumbuhan, yang ditentukan untuk mewakili tiap-tiap periode pertumbuhan. Pada hari ke-14 pukul 06.00 (suhu lingkungan $23^{\circ} \mathrm{C}$ ) sampai dengan pukul 13.00 (suhu lingkungan $35^{\circ} \mathrm{C}$ ) dan Electrical Conductivity (EC)/konduktivitas listrik larutan nutrisi meningkat sejalan dengan meningkatnya suhu lingkungan, dan pada pukul 16.00 (suhu lingkungan $34^{\circ} \mathrm{C}$ ) menurun. Nilai Electrical Conductivity (EC)/konduktivitas listrik tertinggi pada pukul 13.00 pada masing-masing outlet talang, pada kemiringan $2 \%$ nilai Electrical Conductivity (EC)/konduktivitas listrik mencapai $2.70 \mathrm{mS} / \mathrm{cm}$, pada kemiringan $4 \%$ Electrical Conductivity (EC)/konduktivitas listrik 2.66 $\mathrm{mS} / \mathrm{cm}$ dan pada kemiringan $6 \%$ Electrical Conductivity (EC)/konduktivitas listrik sebesar $2.69 \mathrm{mS} / \mathrm{cm}$.

Suhu merupakan salah satu faktor penting dalam budidaya secara hidroponik NFT. Pada tanaman sayuran suhu untuk pertumbuhan yang optimal adalah $23-35^{\circ} \mathrm{C}$ jika suhu melebihi dari 36 ${ }^{\circ} \mathrm{C}$ maka tanaman akan mati. Untuk tetap menjaga pada kondisi suhu yang optimal dilakukan pengecekan rutin untuk suhu lingkungan maupun suhu pada nutrisi. Selain itu, perubahan suhu lingkungan cenderung mempengaruhi reaksi kimia dalam larutan nutrisi sehingga Electrical Conductivity (EC)/konduktivitas listrik pada larutan meningkat. Hal ini sesuai dengan (Karsono, dkk, 2002) yang menyatakan temperatur tinggi mengakibatkan reaksi kimia semakin cepat. Peningkatan suhu akan mengakibatkan reaksi kimia dalam larutan semakin cepat dan pergerakan ion-ion dalam larutan aktif dan cepat. Peningkatan ini akan mengakibatkan nilai Electrical Conductivity (EC)/konduktivitas listrik semakin meningkat.

\section{Hubungan antara Nilai Konduktivitas Listrik (EC) Larutan dengan Jumlah Pupuk yang Dilarutkan dalam 25 Liter Air}

Hubungan antara nilai konduktivitas listrik dengan pupuk yang dilarutkan dalam 25 liter air disajikan dalam grafik berikut ini:

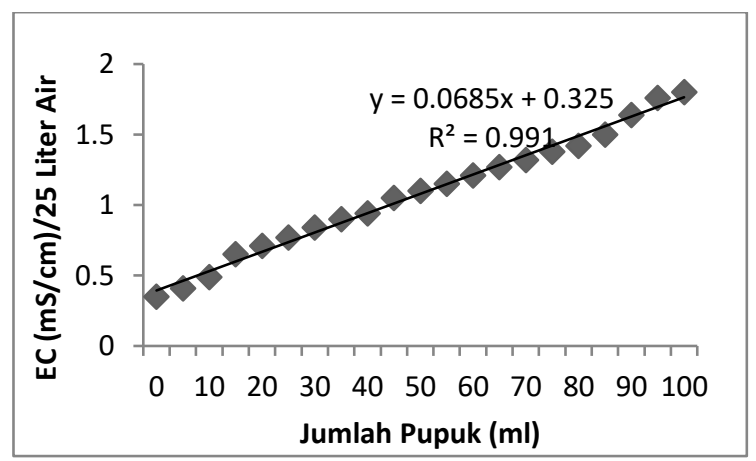

Gambar 7. Grafik Hubungan antara nilai konduktivitas listrik dengan pupuk yang dilarutkan dalam 25 liter air

Electrical Conductivity

(EC)/ konduktivitas listrik berbanding lurus dengan 
banyaknya unsur hara yang terkandung dalam pupuk $\mathrm{AB}$ mix. Semakin banyak unsur hara yang terkandung dalam larutan nutrisi maka semakin tinggi pula nilai Electrical Conductivity (EC)/konduktivitas listrik. Hubungan konduktivitas listrik dengan pupuk yang dilarutkan dalam 25 liter air dapat digunakan untuk menentukan seberapa banyaknya pupuk yang harus dilarutkan dalam bak nutrisi dari awal pertumbuhan, pertengahan tumbuhan dan akhir pertumbuhan. Prayitno (2012) mengatakan bahwa larutan nutrisi yang sesuai untuk budidaya tanaman pakcoy sebaiknya mempunyai EC 1-1,5 $\mathrm{mS} / \mathrm{cm}$ untuk pembibitan, $2,7 \mathrm{mS} / \mathrm{cm}$ untuk pertumbuhan vegetatif, dan 3,2-3,5 $\mathrm{mS} / \mathrm{cm}$ untuk pertumbuhan generatif.

Gambar 7 menunjukkan bahwa semakin banyak larutan nutrisi yang dilarutkan pada 25 liter air, maka semakin tinggi nilai Electrical Conductivity (EC)/konduktivitas listriknya. Sehubungan dengan hal tersebut maka untuk memenuhi Electrical Conductivity (EC)/konduktivitas listrik yang sesuai untuk tanaman, terlebih dahulu dilakukan percobaan untuk mengetahui berapa (ml) larutan nutrisi untuk memenuhi Electrical Conductivity (EC)/konduktivitas listrik yang akan digunakan untuk periode awal, tengah dan akhir pertumbuhan.

\section{Hubungan Suhu Air dengan Suhu Lingkungan}

Hubungan suhu air dan suhu lingkungan didapatkan untuk mengetahui apakah ada pengaruh suhu lingkungan terhadap suhu air yang digunakan untuk nutrisi tanaman.

Hubungan suhu air dan suhu lingkungan dapat dilihat pada grafik berikut ini:

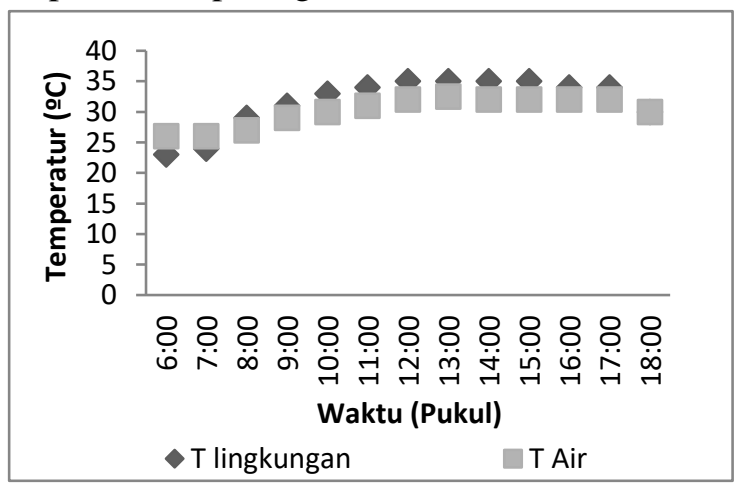

Gambar 8. Grafik Hubungan Suhu Air dengan Suhu Lingkungan
Air adalah salah satu media yang digunakan pada hidroponik NFT (Nutrient Film Technique) dengan aspek fertigasi. Air berfungsi sebagai pengikat unsur hara untuk pertumbuhan tanaman. Untuk tetap menjaga suhu air yang sesuai untuk pertumbuhan tanaman maka pengecekan suhu air terus dicek. Suhu air yang terlalu tinggi akan mempersulit tanaman untuk menyerap unsur hara. Air nutrisi lebih baik dijaga pada kisaran suhu $25-30{ }^{\circ} \mathrm{C}$ jika melebihi dari suhu tersebut maka air tersebut tergolong pada air hangat dan menyebabkan panthogen hidup di Air Nutrisi (contoh Pythium) ini berpengaruh pada berkurangnya kadar oksigen terlarut yang dibutuhkan akar tanaman.

Gambar 8 menunjukkan bahwa hubungan suhu air dengan suhu lingkungan yang diambil pada hari ke-14. Pada grafik tersebut menunjukkan nilai suhu air yang terus meningkat seiring dengan peningkatan suhu lingkungan. Semakin tinggi suhu lingkungan, maka suhu air akan meningkat. Ini disebabkan karena posisi drum nutrisi dan talang yang menghadap sejajar dengan penyinaran matahari. Pada pukul 06.00 suhu lingkungan sebesar $23^{\circ} \mathrm{C}$ dan suhu air sebesar $26^{\circ} \mathrm{C}$. Sedangkan pada suhu lingkungan pada pukul 13.00 sebesar $35^{\circ} \mathrm{C}$ dan suhu air menjadi $32,5^{\circ} \mathrm{C}$. Ini menunjukkan bahwa semakin tinggi suhu lingkungan semakin tinggi pula suhu air.

\section{Evaluasi Talang}

Nilai keseragaman talang yang mempunyai kemiringan $4 \%$ lebih baik untuk tanaman sayuran dibandingkan dengan kemiringan talang $2 \%$ dan $6 \%$, walaupun tidak berbeda jauh. Hal ini disebabkan, talang dengan kemiringan $4 \%$ mempunyai lapisan nutrisi yang lebih tipis $( \pm 3 \mathrm{~mm})$ dibandingkan dengan $2 \%$ $( \pm 5 \mathrm{~mm})$ dan $6 \%( \pm 2 \mathrm{~mm})$. Terlalu tipis aliran nutrisi pada talang akan membuat akar tanaman sulit untuk menyerap unsur hara, sedangkan terlalu tebal aliran nutrisi akan membuat tanaman sulit dalam respirasi. Selain itu, jenis talang mempengaruhi nilai keseragaman karena setiap talang memiliki tingkat kekasaran yang berbedabeda hal ini berpengaruh terhadap debit aliran nutrisi. Semakin halus talang yang digunakan maka aliran air akan lebih cepat dibandingkan dengan yang kasar. Oleh karena itu, untuk meningkatkan nilai keseragaman yang tinggi 
maka pemilihan dan perancangan talang menjadi salah satu faktor untuk mendapatkan nilai keseragaman yang tinggi terutama dalam budidaya hidroponik NFT (Nutrient Film Technique) dalam skala besar.

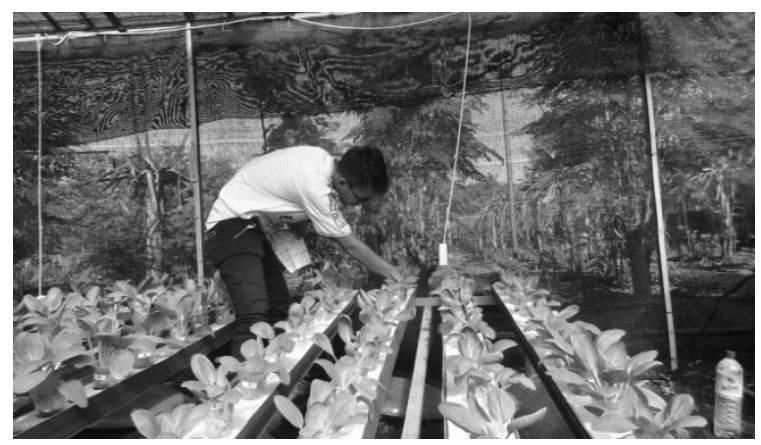

Gambar 9. Proses Pemanenan

Dalam keberlangsungan sistem hidroponik NFT ada beberapa faktor yang harus diperhitungkan demi kelancaran pertumbuhan tanaman diantaranya adalah:

1. Kelembaban dan Suhu yang tidak terlalu tinggi

2. Curah hujan dan pembagian curah hujan sepanjang tahun yang merata sepanjang tahun

3. Intensitas cahaya yang tidak terlalu tinggi yang dapat mengganggu pertumbuhan tanaman. Kelebihan intensitas cahaya akan membuat tanaman menjadi kuning dan rusak kekurangan intensitas cahaya akan membuat tanaman terkena penyakit kutilang (kurus tinggi langsing)

4. Angin yang tidak terlalu keras

5. Elevasi (Ketinggian tempat)

6. Derajat Keasaman $(\mathrm{pH})$

Hal ini sesuai dengan Karsono, dkk (2002), yang menyatakan ekosistem lingkungan mikro di sekeliling tanaman perlu mendapat perhatian khusus karena sifat iklim yang tidak merata sepanjang tahun, misalnya pada musim hujan jumlah air yang berlebih. Ekosistem sangat berpengaruh terhadap keberhasilan bercocok tanam secara hidroponik. Oleh karena itu, faktorfaktor ekosistem tersebut harus dikendalikan, misalnya membuat greenhouse untuk menahan hujan dan meredam cahaya matahari yang berlebihan dan mencegah hama masuk.

\section{Nutrisi Larutan}

Nutrisi hidroponik yang baik adalah nutrisi yang memiliki unsur makro dan mikro salah satu contonhya adalah Nutrisi AB Mix, ABC Mix, ABCD Mix. Untuk itu, pemilihan nutrisi sangat penting sesuai dengan tanaman yang akandi budidayakan.

\section{Air Nutrisi yang bagus (Kualitas Air)}

Kualitas air sangat menentukan dalam bercocok tanam secara hidroponik. air Nutrisi sebaiknya menggunakan Air baku yang bagus (Soft Water), dan alangkah baik apabila disaring/di-filter terlebih dahulu agar garam, kapur, zat besi yang terdapat dalam air berkurang. Air Baku (Soft Water) yang digunakan memiliki nilai TDS (Total Dissolved Solids) antara 0-180 ppm. Jika lebih $180 \mathrm{ppm}$, maka air tersebut dikategorikan Hard Water, hal ini membuat $\mathrm{pH}$ tidak stabil. Jika $\mathrm{pH}$ tidak stabil maka akan mengganggu pertumbuhan tanaman. Selain itu, menjaga suhu air di kisaran $25^{\circ} \mathrm{C}$. Suhu air nutrisi yang hangat bisa menyebabkan panthogen hidup di air nutrisi (contoh Pythium).

\section{Kemiringan talang yang digunakan}

Kemiringan talang pada sistem hidroponik NFT sangat perlu diperhatikan karena akan berpengaruh pada hasil produksi tanaman.

\section{KESIMPULAN DAN SARAN}

\section{Kesimpulan}

1. Sistem hidroponik NFT (Nutrient Film Technique) dengan aspek fertigasi harus memiliki tingkat keseragaman yang tinggi baik pada keseragam debit outlet, keseragaman Electrical Conductivity (EC)/konduktivitas listrik dan keseragaman $\mathrm{pH}$ larutan nutrisi.

2. Nilai keseragaman pada kemiringan talang $4 \%$ tidak berbeda jauh dengan kemiringan talang pada $2 \%$ dan $6 \%$.

3. Suhu air dan suhu lingkungan harus tetap dijaga untuk pertumbuhan tanaman suhu air yang tinggi dapat mengakibatkan tanaman sulit menyerap unsur hara. Sedangkan suhu lingkungan yang tinggi akan membuat tanaman tidak tumbuh dengan normal. 


\section{Saran}

Untuk penelitian selanjutnya diharapakan menggunakan tanaman dengan keseragaman yang telah ditentukan pada masing-masing kemiringan talang.

\section{DAFTAR PUSTAKA}

Anonim. 2011. Tabel Hasil Sensus Penduduk 2010 (online) http://www.bps.go.id/aboutus.php?sp=0, diakses 25 Desember 2015.

Astuti F, SS Asngad, A Asngad. 2016. Efektivitas Air Cucian Beras dan Ekstrak Daun Kelor untuk Pertumbuhan Tanaman Cabai Merah (Capsicum annum L.) dengan Teknik Hidroponik. Publikasi Ilmiah Program Studi Pendidikan Biologi Fakultas Keguruan dan Ilmu Pendidikan Universitas Muhammadiyah Surakarta.

Chadirin, Y. 2001. Teknologi Hidroponik II. Pelatihan Aplikasi Teknologi Hidroponik untuk Pengembangan Agribisnis Perkotaan. CREATA-IPB.

Hochmuth. G.J. 1991. Fertilizer Management for Greenhouse Vegetable. Fla. Coop. Ext. Serv. Florida. p.13-31

Karsono, S., W. Sudarmodjo dan Y. Sutiyoso. 2002. Hidroponik Skala Rumah. Tangga. Agromedia Pustaka. Jakarta

Michael, A. M. 2001. Theory and Practice. Vikas Publishing House PVT. LTD, London.

Prayitno, S. 2012. Nutrisi Hidroponik, Materi Pelatihan. Goodplant Indonesia. Yogyakarta.

Prihmantoro, H. dan Y. H. Indriani. 1999. Hidroponik Buah untuk Bisnis dan Hobi. Penebar Swadaya, Jakarta.

Sapei, A. 2003. Uniformity dan Efisiensi Irigasi Sprinkler dan Drip. Pelatihan Aplikasi Teknologi Irigasi Sprinkler dan Drip. Lembaga Penelitian, Institut Pertanian Bogor, Bogor.
Sapto Wibowo dan Arum Asriyanti S. 2013 Aplikasi Hidroponik NFT pada Budidaya Pakcoy (Brassica rapa chinesis). Jurnal Penelitian Pertanian Terapan Vol. 13 (3): 159-167. Program Studi Agroteknologi Politeknik Banjarnegara.

Sundstrom, A.C., 1982. Simple Hydroponics for Australian Home Gardeners. Melbourne.

Sutiyoso, Y. 2003. Aeroponik Sayuran (Budidaya dengan Sistem Pengabutan). Penebar Swadaya, Jakarta.

Untung, O. 2000. Hidroponik Sistem NFT (Nutrient Film Technique). Penebar Swadaya, Jakarta.

Wijayani, A. dan Widodo W. 2005. Usaha Meningkatkan Kualitas Beberapa Varietas Tomat dengan Sistem Budidaya Hidroponik. Ilmu Pertanian, (12) 1: 77-83. 